\title{
Employees' Motivation in Public and Private Commercial Banks in Bangladesh: A Study on Need-Based Approach
}

\author{
Md. Hasebur Rahman
}

Lecturer, Department of Business Administration, Pabna University of Science and Technology, Bangladesh

\begin{abstract}
Motivation remains a key secrete of managing people at organizational interfaces. Different people from differ background come together within organization having different aims incompatible to organizational aims. Motivation acts as key forces to drive diversified workforce to meet organizational objectives. In Bangladesh Performance of public commercial bank in comparison to the private commercial bank has long been a point of dissuasion. This study has made a comparison between employees of public and private commercial bank in Bangladesh regarding their motivation on the basis of need theories of motivation. Their motivation level was measured and compared on the basis of two major constructs identified from the literature review. These construct are perception about the benefits received from the job, and perception about the job nature and job environment in the banking organization. It is found that employees of private commercial bank scored slightly higher in both the construct however there is no significant differences have been proved about benefit received from the job and perception about job nature and environment. Differences were found between the two groups on the relative perception they placed on existing factors of motivation.
\end{abstract}

Key words: Motivation, Need Theories, Commercial, Bank, Employees

JEL Classification Code: G20; G29

\section{INTRODUCTION}

The success of any organization falls back upon its competent and motivated human resources (Mohiuddin, 2008). Human resources regarded as the most valuable assets and sometimes irreplaceable assets in the organization. It is human resources who set organization's objectives and strategies, design and produce goods and services, quality control and market goods and services. It is simply impossible on the part of an organization to get these activities performed efficiently and effectively unless the people of the organization extend their sincere and voluntary cooperation depending upon the level of motivation an individual has with his or her job, to put forth his or her best to the organization. Employees and their behavior represent strong forces that can enhance or diminish effectiveness of organization. 
With the growing up of the economy of Bangladesh, a dramatic change has been take place in service sector. Both public and private commercial banks are operating in the country with a highly competitive pressure with customized services. Motivation agenda become a driving force for employees of commercial bank to serve internal and external customer with customer demand and satisfaction. Competition with in this industry has made the service gap within and between the public and private commercial banks in Bangladesh. Public sector commercial bank in Bangladesh is also subject to the criticism of being inefficient and unproductive. There is consensus that the public sector organizations are too big, overstaffed, inefficient, and less productive in comparison to private sector organization (Marinakis, 1994; Rowly 1998). Other than a few exceptions, public sector organizations have been characterized with low productivity and repeat loss . On the contrary, the private sector organizations in the country are usually thin, agile, highly productive, and profitable (Jahiruddin, Noor, Mahmudul, 2004). Doing business in different sectors require different strategies and objectives. Global competition, downsizing, reengineering, information technology, and total quality are posing enormous challenges that with dealt managers and management working in banking business. To the context of changing business environment there is hardly any study undertaken to survey the motivation level of employees working in commercial banks with respect to need theories of motivation. An attempt has been made in this study to investigate employees' motivational perception of public and private commercial bank in the country in reference to the need theories of motivation.

\section{Objectives of the Study}

Firstly, objective of the study was to investigate perception of employees on existing motivational factors finally, study is an initiate to measure perceptions of employees of public and commercial bank in Bangladesh about the benefits they receive from the job and test how they difference in their perceptions about job nature and job environment.

\section{LITERATURE REVIEW}

3.1. Concept of Motivation: Motivation becomes an important agenda for managers and management scholars now a days and it will remain in future. Motivation is a general term applying to the entire class of drives, desires, needs, wishes, wants, aims, goals, motives, and incentives. It is a basic psychological process that includes the need-drive-incentive sequence or cycle. Motivation is a process that starts with a physiological or psychological deficiency or need that activates a behavior or a drive that is aimed at a goal or incentive (Luthans, 1998). It also refers to the processes that account for an individual's willingness to exert high level of effort to reach organizational goals, conditioned by the effort's ability to satisfy need (Robbins \& Coulter 2006). Organizational endeavors success or fails depending on the people involved. To keep the people working efficiently, they need to consistently motivate. Money is not only motivating factor. Besides money, there are many other financial and non-financial factors that can keep people happy, hardworking and ambitious. There is responsibility and achievement, recognition, intrinsic interest in the work, the reward system, influence of others, congenial working environment, appreciation, communication, participation in decision making etc. (Kumar, January 2003). Motivated employees in the work place can be termed as those who willingly and voluntarily extend their best efforts in order to help the organization attaining its goal. Motivated employees are sincere, dutiful, and laborious; therefore, need less supervision to expert best performance out of them. 
3.2. Need Theories of Motivation: Needs-based motivation theories are based on the understanding that motivation stems from an individual's desire to fulfill or achieve a need. The essence of these theories is people come to work for satisfaction of different types of needs. People will be motivated to work if their needs are adequately satisfied by the job. The widely mentioned theories of this category are Abraham H. Maslow's Hierarchy of Needs theory, Frederick Herzberg's two-factor theory, Clayton P. Alderfer's Existence Related Growth (ERG) Theory, and David McClelland's Achievement Motivation Theory. In 1943, one of the widely mentioned theories of motivation is the hierarchy of needs theory put forth by psychologist Abraham Maslow, commonly referred to as Maslow's Hierarchy of Needs. Maslow show human needs in the form of a hierarchy, ascending from the lowest to the highest, and he concluded that when one set of needs is satisfied it is no longest serves to motivate. The next higher level of need has to be activated in order to motivate the individual. Maslow's hierarchy is commonly displayed in a pyramid fashion, with the basic needs at the bottom and the higher needs at the top. The essence of this theory is that as the employees climb, their concern for higher order needs such as good job environment, recognition, responsibility, and power increases. Frederick Herzberg of U.S.A. has developed (1959) a classical theory of work motivation by differentiating between motivational \& maintenance factors in job situation. Herzberg called two sets of factors "Hygiene factors" and "motivational factor". The hygiene factors support mental health and are potent dissatisfies. They are necessary to avoid dissatisfaction just as hygiene prevents sickness. They are presence does not motivate employees but when they are absent employees become dissatisfied. They are also recognized as maintenance factors including company policy and administration, Salary, Working conditions, Security of service, co-operation, and supervision. The motivational factors or satisfies lead to high job satisfaction and strong motivation. These are related to achievement, progress, recognition, reward, possibility of development, training, advancement, and responsibility. Clayton P. Alderfer first presented the ERG Theory of Motivation in 1969 in his article, "An Empirical Test of a New Theory of Human Need." The ERG theory attempted to improve upon Maslow's needs hierarchy by allowing more flexibility of movement between needs. Alderfer decreased the number of levels and allowed the order of the needs to vary by the individual; he also allowed for different needs to be pursued simultaneously. Alderfer's ERG needs theory has slightly more research support than Maslow. ERG states that any or all needs can be activated simultaneously. David McClelland in his book (1961), The Achieving Society, identified three types of motivational needs, on which he based a model to describe one's style with regard to being motivated and motivating others, depending on the different level of needs within the individual. These are need for Achievement, need for Power and need for Affiliation.

Motivation theories ranging from the classical one to the most temporary one were explored to develop the construct to measure and compare level of motivation of public and private commercial banks in Bangladesh. A Related survey has been conducted by Jahiruddin, Noor, and Mahmudul in 2004 " Study reveals that private sector managers are more motivated than public sector managers both in terms of Hygiene factors and Motivational factors". It also suggested that not only the level of motivation, but also the motivating factors are different between these two groups according to the importance they place on them. We know from the study that how banking sector Bangladesh follow 
need based model in ranking their employees' needs. A different ranking of employees' needs is observed at both lower and upper levels in commercial bank in Bangladesh.

\section{Hypotheses Of THE StUdy}

From the literature review it is seen that benefit that employees receive from the jobs are vital component for their motivation. Benefits include monetary and non-monetary at the same time present and future benefits. Industrial psychologists describe the relationship between an employee's motivation and his or her perception of equitable or inequitable treatment. An individual's motivation level is correlated to his perception of equity, fairness and justice practiced by the employee or employees outside the employee's present organization. Higher is individual's perception of fairness, greater is the motivation level and vice versa. Therefore first hypothesis of the study is:

$\mathbf{H}_{1}$ : There is significant difference between employees of public and private commercial banks in their perceptions about the benefits they receive from the job.

Previously discussed literature also shows that nature of job and the environment of the workplace is a vital factor for motivation, especially for white-collar employees. Providing a motivating work environment including challenging and interesting work, comfortable physical environment, formal and informal communication, autonomy, job security, employee involvement, good interpersonal communication, are positively correlated to better performance. From these evidence found from the literature, researcher developed the following hypotheses:

$\mathbf{H}_{2}$ : There is significant difference between the employees of public and private commercial banks in their perceptions about job nature and job environment.

Based on the literature review and exploratory research carried out, 10 variables (Table-1) were identified perception of employees on existing motivational factors of employees of commercial bank. These factors can be categories into two groups firstly, "Lower order need" by Maslow and "Hygiene Factor" by Herzberg and secondly "Higher Order Need" by Maslow and "Motivation Factors" by Herzberg.

Motivations of employee of commercial bank were compared with respect to these constructs. In order to measure the constructs, 10 questions were presented.

\section{Methodology}

5.1. Instrument for data collection: This study mainly based on primary data originating from a survey. For this purpose a constructed questionnaire was developed. Excepting the questions regarding demographic characteristics of the respondents the issues relating to employees' motivation on need-based approach were investigated through 5 point Brayfield-Rothe Scale (1951) based questions.

A pilot study on 10 respondents was conducted using the draft questionnaire. As the outcome of this phase few initially selected variables were dropped to avoid multicoliniarity problem. As well some rephrasing was done to arrive at final version of questionnaire for this study. Final questionnaire was put into operation by the way of mail and personal survey.

5.2. Sample: Because of the lack of sampling frame, convenient method of sampling was used. There was no source available for the address of the employees of commercial bank. Therefore, friends, relatives, and other informal reference group were used to locate the potential respondents from commercial bank in Bangladesh. Questionnaires were sent by email and postage mail to 120 employees working in commercial bank in sample 
organization. Number of initial replies received was 60. After a screening first round replies a second round personal contract conducted by researcher and finally 80 respondents were taken for this study.

5.3. Analysis of data: A sample consists of 80 employees working at the executive position in the sample organization. The data for the present study are obtained by the administration of a questionnaire comprising two parts. The first part contains columns for personal information and the second one includes perceptions of employees of public and commercial bank in Bangladesh about the benefits they receive from the job and how they difference in their perceptions about job nature and job environment. Measuring scale as constructed and standardized by Brayfield-Rothe Scale (1951). The scale consists of 10 statements concerning perceptions of employees of public and commercial bank in Bangladesh about the benefits they receive from the job and how they difference in their perceptions about job nature and job environment. For each statement has five options/ points such as strongly agree/ 5, agree/ 4, undecided/ 3, disagree/ 2, and strongly disagree/ 1.

SPSS Statistics software package was used for statistical analysis. Reliability of data was measured by using the Chronbach's Alpha (Cornbach, 1951). Chronbach Alpha was 0.799 and 0.587 for public and private commercial banks respectively. Alpha in both cases were higher than that is suggested by Nunnally (1978) and therefore data collected can be considered reliable. Descriptive statistical technique such as mean and standard deviation were used to measure the mean scores and their variability, One way ANOVA was used to compare the difference between the scores of each statement.

\section{RESULTS AND DISCUSSION}

Perception of employees on existing motivational factors: Table 1 represents a relative picture of employees the public and private commercial banks in Bangladesh on existing motivational factors on organizational interfaces.

Table 1: Perception of employees on existing motivational factors

\begin{tabular}{|c|c|c|c|c|c|c|}
\hline \multirow[b]{2}{*}{ Factor } & \multicolumn{3}{|c|}{ Public Commercial Bank } & \multicolumn{3}{|c|}{ Private Commercial Bank } \\
\hline & Ranking & $\bar{X}$ & $\sigma$ & Ranking & $\bar{X}$ & $\sigma$ \\
\hline \multicolumn{7}{|l|}{ Lower order needs/ Hygiene Factors } \\
\hline Salary & 8 & 3.20 & 1.324 & 8 & 3.57 & 1.083 \\
\hline Job security & 4 & 3.52 & 1.240 & 9 & 3.53 & 1.132 \\
\hline Fringe benefits & 10 & 2.83 & .874 & 10 & 2.97 & 1.230 \\
\hline Security for future & 5 & 3.50 & 1.240 & 5 & 3.70 & 1.067 \\
\hline Good interpersonal relations & 2 & 3.65 & 1.145 & 1 & 4.20 & .723 \\
\hline \multicolumn{7}{|c|}{ Higher order needs/ Motivational Factors } \\
\hline Training and development & 6 & 3.30 & 1.344 & 3 & 4.05 & .749 \\
\hline Prestige and social dignity & 1 & 4.05 & .876 & 2 & 4.13 & .516 \\
\hline Reward and recognition & 7 & 3.25 & 1.316 & 7 & 3.60 & .778 \\
\hline Growth/Promotion & 9 & 2.88 & 1.285 & 6 & 3.68 & .997 \\
\hline Open communication & 3 & 3.53 & 1.086 & 4 & 3.80 & .758 \\
\hline
\end{tabular}

Source: Field Survey, 2013.

It is found in the table 1 that, employees of commercial bank perceived that their present jobs have prestige and social dignity and there is a good interpersonal relationship among 
the employees of commercial banks in Bangladesh. Therefore social dignity and status is perceived as first preference and good interpersonal relationship as second preference for public commercial and vice versa for private commercial bank in Bangladesh. Salary as a basic need remain $8^{\text {th }}$ position because of employees of both commercial banks; their employees perceive that their remuneration is inconsistent to workload and job responsibility. Job security perceived as $4^{\text {th }}$ and $9^{\text {th }}$ for public and private commercial banks respectively, it indicates that public commercial bank has more autonomy at work than private commercial bank and interestingly high variability observed in public sector counterparts. However table 1 represents overall perception of employees on existing motivational factors.

Perception about Lower Order Needs/Hygiene Factors: This section represents and discusses result of the test of hypotheses and comparison of the overall motivation of the study group. Table 2 shows the perception scores of two groups of respondents on the statements related to five lower order needs/ hygiene factors.

Table 2: Difference in the perception about benefit received from the job

\begin{tabular}{|c|l|r|r|r|r|r|r|}
\hline \multicolumn{2}{|c|}{ Statements } & \multicolumn{2}{c|}{ Public } & \multicolumn{2}{c|}{ Private } & \multicolumn{2}{c|}{ Comparison } \\
\cline { 3 - 8 } & $\bar{X}$ & $\sigma$ & $\bar{X}$ & $\sigma$ & $\mathrm{F}$ & $\mathrm{p}$ \\
\hline 1. & $\begin{array}{l}\text { "I receive adequate salary from } \\
\text { my job" }\end{array}$ & 2.58 & 1.13 & 3.15 & 1.145 & 5.113 & .027 \\
\hline 2. & $\begin{array}{l}\text { "My job ensures a secured future } \\
\text { for me and my family" }\end{array}$ & 3.48 & 1.396 & 3.88 & .853 & 2.392 & .126 \\
\hline 3. & $\begin{array}{l}\text { "My job gives me dignity and } \\
\text { social status" }\end{array}$ & 4.30 & .608 & 4.20 & .464 & .684 & .411 \\
\hline 4. & $\begin{array}{l}\text { "I can materialize my career } \\
\text { ambition in my jobs" }\end{array}$ & 3.50 & .987 & 3.45 & .876 & .057 & .811 \\
\hline 5. & $\begin{array}{l}\text { "There are adequate training } \\
\text { and development program } \\
\text { in my jobs to fulfill my personal } \\
\text { growth potentials" }\end{array}$ & 3.15 & 1.406 & 4.03 & .862 & 11.260 & .001 \\
\hline Average Score: & 3.4 & 1.10 & 3.75 & 0.84 & 3.9012 & 0.2752 \\
\hline
\end{tabular}

Table 2 is a summary of findings related to employees perception on benefits received from the organizations. From the above table it can be observed that salary received from the organization is higher of private commercial bank compare to public commercial bank counterpart is statistically significant. Also as the standard deviations suggest, there exist higher variability in the perception of employees of private commercial bank.

Perception of employees of private commercial bank about the future security, social dignity and status, materialize career ambition in present jobs are slightly higher than public commercial. Here ANNOVA results represent statistically insignificant in perceptions in this case. Adequacy of training and development programs for enhancing personal growth and potentiality are higher than that of public commercial bank counterparts is statistically significant.

Perception about the overall benefits received from the organization is slightly higher than that of public commercial bank.it is also interesting that there is a high variability of each statement of public commercial bank counterparts. The average $p$ value of the above table is higher than 0.05 in every case, indicates that all the differences are statistically significant and therefore we conclude that the $1^{\text {st }}$ hypothesis "There is significant difference 
between employees of public and private commercial banks in their perceptions about the benefits they receive from the job" is rejected ( $\mathrm{p}>.05)$

The perception about job nature and job environment: The second construct measures and compare the perception of employees of public and private commercial bank about job nature and environment that is so called higher order needs/ motivational factors.

Table 3: Difference in the perception about job nature and job environment

\begin{tabular}{|c|l|c|c|c|c|c|c|c|}
\hline \multicolumn{2}{|c|}{ Statements } & \multicolumn{2}{c|}{ Public } & \multicolumn{2}{c|}{ Private } & \multicolumn{2}{c|}{ Comparison } \\
\cline { 3 - 8 } & $\bar{X}$ & $\sigma$ & $\bar{X}$ & $\sigma$ & $\mathrm{F}$ & $\mathrm{p}$ \\
\hline 1. & "My job is interesting" & 2.78 & 1.330 & 3.35 & .921 & 5.053 & .027 \\
\hline 2. & 3.10 & 1.033 & 4.23 & .920 & 26.475 & .000 \\
& $\begin{array}{l}\text { "I work in a comfortable } \\
\text { physical environment" }\end{array}$ & & & & & & & \\
\hline 3. & $\begin{array}{l}\text { "I work in an environment of mutual } \\
\text { cooperation among the employees" }\end{array}$ & 4.00 & .751 & 4.20 & .823 & 1.289 & .260 \\
\hline 4. & $\begin{array}{l}\text { "There is a good interpersonal } \\
\text { relationship among all levels of } \\
\text { employees in my organization" }\end{array}$ & 3.83 & .844 & 3.95 & .815 & .454 & .502 \\
\hline 5. & $\begin{array}{l}\text { "There is good employees } \\
\text { management relationship in } \\
\text { my organization" }\end{array}$ & 3.43 & 1.152 & 3.65 & .921 & .930 & .338 \\
\hline \multicolumn{2}{|l|}{ Average Score: } & 3.428 & 1.022 & 3.876 & 0.88 & 6.8402 & 0.2254 \\
\hline
\end{tabular}

As shown above table, employees of private commercial bank score higher in all the statements, which obviously make their overall score higher in this construct. It also reveals that respondents of private commercial bank have low variability of all case. As indicated by the average values of $\mathrm{p}$ as a whole are statistically insignificant, which is higher than 0.05 in three cases. so we can conclude that $2^{\text {nd }}$ hypothesis" There is significant difference between the employees of public and private commercial banks in their perceptions about job nature and job environment" is rejected ( $\mathrm{p}>.05)$.

\section{ConCLUSION AND RECOMMENDATION}

The study reveals that the employee of private commercial bank is slightly more motivate that of public commercial bank. It also suggested that there is a difference observed between perception of employees on existing motivational factors on public and private commercial bank. Perception of employees on benefits received from the jobs and perception about job nature and job environment are statistically proved same in this study. Although above mentioned measures theoretically confirm there is a difference in perceptions on benefits received from the job and job nature and environment, this study contradicts with some previous researchers found in literature survey.

However his study can be useful for academicians and decision makers of both types of organizations. It provides massage to top management of both organizations that motivation is key secret of organizational effectiveness. To keep the people working efficiently, they need to consistently motivate. Money is not sole motivating factor. Besides money, there are many other financial and non-financial factors that can keep people happy, hardworking and ambitious for organizational success. Good interpersonal relations, prestige and social dignity, open communication, training and development, job security, reward and recognition, security for future, growth/promotion are perceived as key motivating factors 
in commercial banks in Bangladesh. Management should recognize that employees and their behavior represent strong forces that can diminish or enhance effectiveness of every organization. Motivated employees are most distinctive resource in competitive business environment. So it is regular program of management to keep motivation as an integral diver for managing diverse employees in banking organization.

\section{RefERENCE}

[1] Khan Mohiuddin, "Job Satisfaction of the Public Sector Industrial Managers in Bangladesh: A Case Study of Rajshahi Jute Mills", Rajshahi University Journal of Social Science and Business Studies, Vol. 16, pp. 165.

[2] Marinakis A E (1994). "Private Sector Employment In Developing Countries: An Overview of Past and Present Trends". International Journal of Public Sector Management. Vol. 7, No.2, pp. 50-68.

[3] Rowly, J (1998) "Quality Management in Public Sector: Some Perspective from Service". Total Quality Management. Vol. 9, No. 2-3, pp. 321-333.

[4] Uddin, Nobi and Hasan "Employees' Motivation in Public and Commercial Banks in Bangladesh: A study on Need-based Approach" The Business Review, Vol. 4, Number 1 \& 2, July to December, 2004.

[5] Luthans F., Organizational Behavior, Eighth Edition, Irwin-McGraw Hill, India, 1998, pp.161.

[6] Robbins, Stephen P. \& Coulter, Mary, Management, Prentice-Hall of India, New Delhi, 2006.

[7] Maslow, A.H., 'A Theory of Human Motivation', Psychological Review, July 1943, pp. 370-396.

[8] Herzberg, F.I., 'One more time: How do you motivate employees?', Harvard Business Review, Sep/Oct 1987, Vol. 65 Issue 5, pp.109-120.

[9] Alderfer, C.P., 'Existence, Relatedness and Growth: Human Need in Organizational Settings'. The Free Press, N.Y., 1972.

[10] McClelland, David C. "The Achieving Society", Princeton, NJ, 1961.

[11] Kumar, op.cit.,pp.34-36.

[12] Cronbach L.J (1951) "Coefficient Alpha and Internal Structure of Test". Psychometrika. Vol. 16, pp.297-334. 